\title{
AN IMPROVEMENT OF THE LITHUANIAN EMERGENCY MEDICAL ASSISTANCE SYSTEM MANAGEMENT
}

\author{
Rimantas Stašys*, Gintautas Virketis**
}

\begin{abstract}
Background. This article discusses an improvement of the emergency medical assistance system in Lithuania. Health care reform in Lithuania has been going on for three decades, but despite the understanding that the health care management has to be effective and methodologically sound it cannot be characterised as consistent, comprehensive, and well-coordinated. The authors explore the methods of how to adapt emergency medical assistance system in Lithuania to the changing environmental factors, the advances of science and information technologies, and to the legal WHO and EU requirements.
\end{abstract}

Research aims. The aim of this study was to define the key emergency medical assistance concepts and management principals, analyse emergency medical assistance system models in foreign countries and use the results to create a theory for the emergency medical assistance management, determine the deficiencies in the Lithuanian emergency medical assistance system as well as propose tools to improve it and define emergency medical assistance management subsystems.

Methodology. Research methods include quantitative descriptive research through a structured questionnaire survey; data statistical analysis (chi-square, mean) methods, modelling, and graphic representation. The internal consistency of the questionnaire scale was assessed by the Cronbach's Alpha coefficient.

Key findings. Problem areas of the emergency medical assistance were grouped based on their impact on the social or economic state in the country. It was the basis of the improvement of the emergency medical assistance management and integration. A model for the management of the emergency medical assistance system in Lithuania has been developed and based on the system principle where integral parts are linked by internal relations between health care management subjects; resources; and outcomes. Five subsystems: supervision of emergency medical assistance, patient inter-hospital transportation, information, and patient flow management, as well as the public education and information have been defined.

Keywords: emergency medical assistance (EMA), improvement, management, system.

* Klaipeda University. E-mail: rimantas.stasys@ku.lt

** Klaipeda University. E-mail: virketis@kul.lt 


\section{INTRODUCTION}

As stated in the World Health Organisation (WHO) Forum, the reduction in mortality rates is the greatest challenge for public health organisations. The achievement of the goal requires new strategies and appropriate management of the preventive systems, as well as human and financial resources (Global Forum on Trauma Care, 2009, WHO). The WHO recognised that an improvement in the planning and organisation of the preparedness for injuries and emergencies is an essential part of the provision of integrated health care services, which also plays an important role in the preparation for, and response to, mass events. Planning and organisation of emergency medical assistance (hereinafter: EMA) services reduces mortality and disabilities and protects against other health disorders caused by everyday injuries (Tintinalli et al., 2010).

The Lithuanian health care system, influenced by the political, economic, social, cultural, medical, and other factors, seeks not only to constantly improve the health of the population, but also address the rapid growth of the emergency medical care needs. However, constantly changing the health care system's internal and external factors result in new and unfavourable trends such as limited health care resources, rising health care costs, lack of human resources, population aging, disease migration, lower patients' responsibly for their own health and the increasing number of complaints about the poor quality of the services provided, the increasing demand for health services and so on. Therefore it is important for health care policy makers and strategy developers, health care management professionals, and health care service providers to combine their efforts for the development of universally accessible and acceptable quality health care services as well as optimally meet the growing needs of the society.

As indicated in the Lithuania's Health System Development Dimensions 2011-2020 prepared by the Republic of Lithuania Ministry of Health, no universal and the most effective health care system organisation model has been developed, and each country has to develop its own model based on its historical and cultural traditions, economic situation, and other factors (VŽ, No. 73-3498, 2011). The management of the EMA system is broad, covering different interdisciplinary 
areas and has not been studied much in the works of the Lithuanian scientists; therefore, this research is relevant from both the scientific and practical viewpoints.

\section{THEORETICAL BACKGROUND OF THE EMA SYSTEM MANAGEMENT}

Even though the concept of EMA has been frequently used in the areas of medicine and law, it does not have a clear definition in the science of management. In foreign scientific literature, one finds such terms as emergency care, urgent care, immediate care, or extra care commonly used in the English language to define instant help. However, both from the scientific and practical viewpoints the EMA concept is best expressed by the English term emergency care, covering the following factors:

- the unexpectedness of an event;

- a poor (life-threatening) state of health;

- the urgency of aid (to be provided immediately, without delay);

- proficiency of aid (the need for skilled care and inpatient services).

Given the above-named factors, the author proposed the following EMA concept definition: Emergency medical assistance is a qualified medical assistance provided due to an unexpected, severe medical condition within the shortest reasonable time.

Since 1970s the mode of emergency health care delivery in pre-hospital environment evolved around two main models of EMA with distinct features. The two models are the Anglo-American and the Franco-German model. Both models observe the same principle: by means of contemporary technologies and doctor's services, to provide patients with EMA services and simultaneously seek to ensure the compliance of the services with the highest possible quality standards (Anthony, 2011). The essential differences between the Franco-German and Anglo-American EMA system management models have been revealed through a comparison of the models by individual traits.

The Franco-German model of emergency medical service (hereinafter: EMS) delivery is based on the "stay and stabilise" philosophy. The motive of this model is to bring the hospital to patients. Countries such as Germany, France, Greece, Malta, and Austria have well-developed Franco-German EMA systems. The Anglo-American model is based 
around "scoop and run" philosophy. The aim of this model is to rapidly bring patients to the hospital with less pre-hospital interventions. It is usually allied with public safety services such as police or fire departments rather than public health services and hospitals. Almost all patients in the Anglo-American model are transported by EMS personnel to the developed Emergency Departments rather than hospital wards. Countries which use this model of EMA delivery include the United States, Canada, New Zealand, the Sultanate of Oman, and Australia. Based on the views of scientists (e.g., Kaluzny \& Shortell, 2006; Hodkinson \& Walis, 2010), one can state that none of the individual health care management models is able to provide all the opportunities, however, different models offer various useful insights into the objectives, contexts, and management functions. A conclusion follows that, in the future provision of the EMA services, the key role will be played not by doctors, but by other health care specialists.

According to Donaldson (1996), health care needs can only be met through the use of health care services which are the result of the system operation. The system consists of constantly communicating and interrelated organisations and groups which make up the forming whole. The author of the article presents a theoretical EMA system management model developed by him and consisting of the following elements: admission and discharge; structural components; internal relations between the components; integration with the health system; levels of service provision; objectives (functions) and processes for the objective achievement; feedback for the management improvement assurance; the boundaries of the system, separating the system-and non-system elements; and the external environment and relations through which integration with other systems takes place (see Figure 1). The EMA provision is activated by an event: an accident or acute exacerbation of a chronic disease.

The EMA system is a sociotechnical system whose resources consist of information, legal and organisational regulations, technologies, material resources, and human and financial resources. The EMA system consists of the following structural components: patients, human resources, material and financial resources, equipment, information resources, legal regulation, objectives, accessibility, transport, medical management, health care activities, relations and communication, staff training, public education, and evaluation. The internal relations of the EMA system unite all the system components and ensure a fluent 


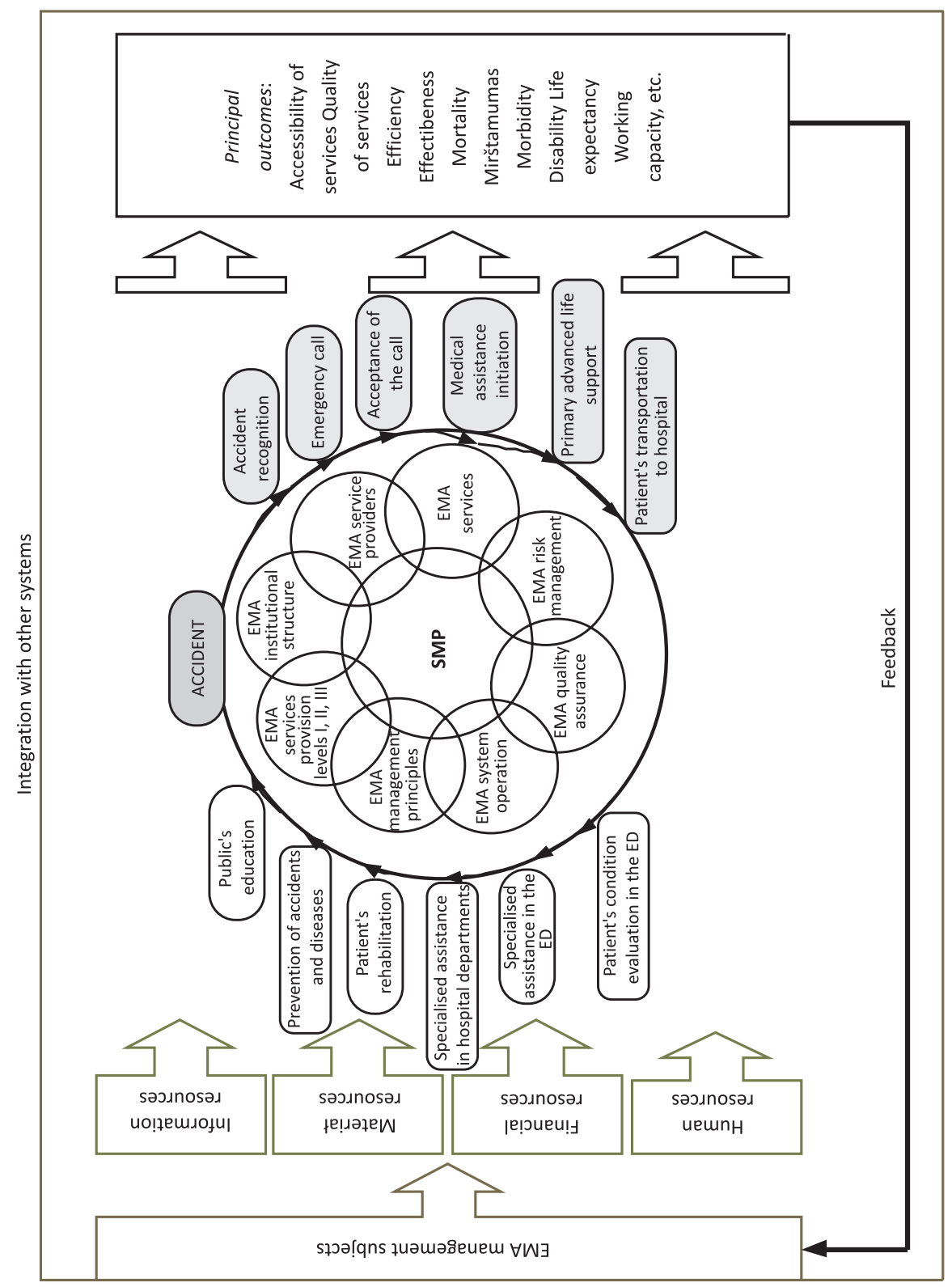

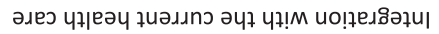

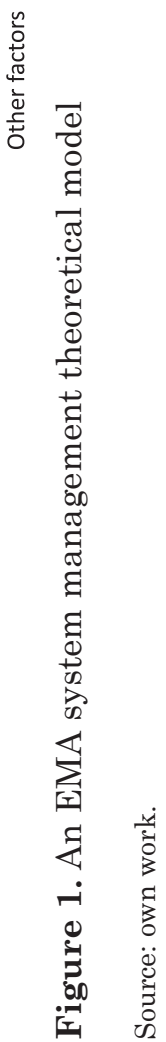


flow between them. The EMA system is maximally integrated with the current health care system, since they are related by the same service provision stages (pre-hospital and hospital), the factors of the changing environment, the demographic and clinical specificity of the population (children, adults, pregnant women, cardiac patients, trauma patients, poisoning cases, etc.), the elements of the provided health care (public health, primary care, rehabilitation), and the management structure and process components. In the developed model, the nucleus is presented as a multi-layer circle, since that is the best way to present the structural components.

The system, even though it claims self-regulation, is managed. Based on the impact on the event, four principles have been traditionally identified in the EMA system management: prevention, preparation (planning), response, and assistance (treatment). The essence is to ensure the best effective prevention of accidents, injuries, and diseases by taking all the necessary precautions, staff and public education, and an effective use of necessary resources. The EMA system follows the main management principles and ensures four principal fields of activity: public safety, public health, response to emergencies, and health care. The EMA system management is based on the following fundamental provisions (Principles of Emergency Management, 2007): comprehensiveness, progressiveness, risk management, integrity, communication, coordination, flexibility, and professionalism.

Based on the theoretical background and the concepts of the EMA system and the EMA system management, we propose the following definition of EMA: emergency medical assistance is a system of medical personal, infrastructure, finance and other elements and relationship between them used to ensure effective, affordable and high quality local, regional, and national medical services. Emergency medical assistance management includes a management of the resources, processes, and tools to ensure high quality and affordable emergency medical assistance.

\section{METHODOLOGY}

The quantitative research through a structured questionnaire survey was conducted in three stages. Stage 1 included respondent sampling and instrument development; in Stage 2 the data was collected (the 
respondents' survey); and in Stage 3 the outcomes were analysed and summarised. The heads of hospitals and ambulance service institutions, intensive care units, and emergency departments have been surveyed. During the survey, Lithuania altogether had 60 hospitals and 19 ambulance stations. In accordance with the selection criteria, 49 hospitals were chosen to participate in the survey. Nine or $18.4 \%$ national hospitals, 11 or $22.4 \%$ regional hospitals and 29 or $59.2 \%$ district hospitals as well as 19 (100\%) ambulance stations were fit for the purpose. The hospitals that fit to the selection criteria employed 168 individuals who met the requirements for the respondent status. A minimal necessary number of respondents was established in order to draw statistically significant conclusions. A 5-percent confidence interval and a 95-percent confidence level were chosen to calculate the sample for the population size. Based on the population of 168 individuals, the confidence interval of $5 \%$ and the confidence level of $95 \%$, the sample size of the respondents was 117 .

The questions in the survey reflected three principal stages of the research process: the evaluation of the current EMA system management situation, the identification of the ways and means for the improvement of the current EMA system management, and the assessment of the purposefulness of the proposed ways and means. The questions in the questionnaire covered the following problematic areas: the concepts of EMA, the organisational issues, human resources, the management of EMA patient flows and inter-hospital patient transportation. To assess the internal consistency of the questionnaire scale, the Cronbach's alpha coefficient value was established. According to the Cronbach's alpha, internal consistency for Questionnaire 1 was. 635, .804 for Questionnaire 2, .942 for Questionnaire 3, and .881 for Questionnaire 4. These values of the Cronbach's alpha coefficient met the requirements for the internal consistency of the questionnaire.

The survey was carried out online from 13 February 2015 to 20 April 2015 (at: Apklausa.lt). The questionnaires were properly filled out by 118 respondents, including 35 Heads of intensive care units (Type 1 respondents), 31 Heads of emergency departments (Type 2 respondents), 33 Heads of hospitals (Type 3 respondents), and 19 Heads of ambulance services (Type 4 respondents). The questionnaires were not filled out, or filled out improperly, by 69 out of 168 Type 1 , Type 2, and Type 3 respondents meeting the selection criteria; their response rate was $58.9 \%$. There were 19 Type 7 respondents; and all 
of them properly filled out the questionnaires; therefore the response rate of $100 \%$ was achieved. Properly filled out questionnaires indicated the respondent's gender and provided answers to the majority of the questions.

SPSS 21.0 was used for the analysis of the results. The relationship between the nominal characteristics was assessed by the chi-square $\left(\mathrm{x}^{2}\right)$ criterion, and the relationship between the interval variables was assessed by the comparison of the means. $P<.05$ was chosen to assess statistically significant differences and $p<.01$ - very significant differences. Likert-type scale responses were calculated on the 5-point scales, where point one was a direct opposite to point five, and the option six with the value $I$ do not know was interpreted as an unanswered question.

Altogether, 118 respondents participated in the survey, with women predominating: 64 (54.2\%) of women and 54 (45.8\%) of men. The distribution of the respondents' age was also rather uneven: 60 year or older respondents accounted for merely $14.6 \%$, those aged 50 to 59 accounted for the largest group (49.0\%), and the remaining group (36.5\%) were the respondents aged 30 to 49 . The greatest part of the respondents represented hospitals founded by municipalities (77 or $75 \%$ ), and nearly one third of the respondents represented institutions founded by the National Ministry of Health. The majority of the respondents came from the district hospitals subordinate to the municipalities (44.8\%), slightly fewer representatives were from the regional hospitals subordinate to the Ministry of Health (33.3\%), and the smallest group of the representatives were from the national hospitals subordinate to the Ministry of Health (21.9\%). In terms of regions, the respondents of the survey covered all the major Lithuanian cities and the greater part of the Lithuanian territory, in general.

\section{RESULTS}

The following problematic areas were identified by the structured questionnaire: how executives understood and treated the fundamental EMA concepts and the current model of the pre-hospital EMA provision. The survey identified the following weaknesses in the emergency medical assistance system management in Lithuania: insufficient legal regulation of the EMA services; inadequate EMA evaluation 
levels resulting in too large patient flows; a shortage of developed and approved EMA performance standards, algorithms, or protocols; a shortage of staff and their inadequate qualification and competences; a lack of quantitative and qualitative performance measurement indicators. It was discovered that the performance evaluation of the EMA does not exist and there is an absence of the regulation of the patient inter-hospital transportation as well as a lack of funding for EMA services and insufficient public information and education.

Qualitative EMA service provision indicators do not exist. Common protocols that would facilitate the evaluation of the patient's condition and their transfer to other departments do not exist, either. The emergency staff do not have sufficient leverage to decide whether a patient needs to be transported to a medical institution or whether they need to be hospitalised, etc. As proved by the survey data, in quite a few cases, the patients' demand to be taken to hospital may be considered as their adaptation to the insufficiently well functioning system in the provision of emergency assistance and the exaggerated understanding of patients' rights.

Based on the survey outcomes, which also confirmed the proposed measures appropriate for the EMA management, the subsystems of the EMA system management where identified and combined into a model of emergency medical assistance system management (see Figure 2). The EMA system management model is integrated with the current health care system and other systems and affected by the changing environment and other external factors. The worked-out model corresponds to the system principle-based theoretical model, however, it differs from it by the improvement measures proposed during the empirical research and the identified subsystems. The model is based on the honeycomb principle: the nucleus (an emergency medical assistance subsystem) and six components, encircling the nucleus and interrelated by direct or indirect (through another component of the model) internal links: a control subject subsystem, a resource subsystem, a patient flow management subsystem, an inter-hospital transportation subsystem, an information subsystem, and a public's education and information subsystem.

The research showed that the demand for patient interhospital transportation is great. The major reason for that is the legally restricted institutions' activity, which prevent them from providing certain services. In more complex cases, a reanimobile is chosen for 
patient transportation, however, the protocols of the transferred patient's condition evaluation do not exist. The hospital representatives were unanimous in indicating that the funding for the provided EMA services and the legal regulation were insufficient, which prevented effective and high quality provision of EMA services.

For the principal measure of the EMA patient flow regulation, i.e. a five-level triage system, the following categories were chosen by the respondents: critical condition, urgent, ambulatory, immediate, and non-urgent. The categories essentially covered all the states from critical to ambulatory. After arranging them in the logical perception of the condition severity, the sequence looked as follows (from the most to the least severe): critical, immediate, urgent, non-urgent, and ambulatory. Instead of the immediate, the author proposed a more practical title of very urgent, given individual opinions of the respondents (e.g., "one has to understand that ambulances have no wings, and the time of the arrival is limited by that"; "the concept of immediate is fine, however, that is only a word, in practice immediate cases never exist"). These categories serve as the fundamental instrument for the patients' condition evaluation, triage, the order of assistance delivery, and the formation of the waiting queues. As established by the research, the patients' condition evaluation by AS or ED, supported by the EMA level requirements for the beginning of the assistance delivery, was statistically very significant $(p<.01)$ : "reduces the waiting time during which patients should start getting EMA" and "improves the consequences after severe injuries". To sum up the obtained data, one could conclude that in order to improve the primary patients' condition evaluation a special attention ought to be paid to the implementation of the advanced evaluation measures and to staff training.

The research aimed to find out whether the respondent opinions on where patients ought to be transported when the type/diagnosis of the disease/injury was clear and when they were obscure differed. In both cases, in the event of a patient's severe condition and a clear or obscure diagnosis, the majority of the respondents believed they ought to be transported to the nearest appropriate level hospital or to the functional cluster centre, provided there was an opportunity to provide assistance during the transportation and thus to ensure the patient's safety $(p<.01)$. The opinions expressed in the answers complied with the foreign authors' data to the effect that patients ought to be best transported not to the nearest, as it might seem in the evaluation of 
the answers, but to the nearest appropriate level medical institution in accordance with the character of the injury or the disease. The nearest appropriate level hospital does not have to mean the nearest hospital.

Additionally, the research results indicated that the majority of the patients who need emergency care are brought to the hospitals but less patients are admitted to the hospitals. Therefore, more burden falls on the primary care staff and patients have to wait longer for the care. The declining number of hospital patients might be associated with the inadequate hospital capacity and resources due to the restructuring of the medical institutions. The increasing number of patient transportation to the hospitals is associated with the emergency care concept, service integration, and the restructuring of the personal health care facilities. A detailed analysis on how many patients sought primary care physician services during 2001-2015 cannot be performed due to the changes in the patient data collection. However, the number of visits to the primary care facilities has increased significantly by 5.9 visits and the necessary medical care compared to the overall medical services increased slightly by $5.8 \%$. Considering the fact that the number of older Lithuanians with more chronic illnesses has increased over the last fifteen years it can be stated that the need for the emergency care has grown.

Based on the survey outcomes, which confirmed the proposed measures are appropriate for the EMA management and the subsystems of the EMA system management we identified and developed a model of emergency medical assistance system management (see Figure 2).

The EMA system management model is integrated with the current health care system and other systems and affected by the changing environment and other external factors. The developed model corresponds to the system principle-based theoretical model, however, it differs from it by the improvement measures proposed during the empirical research and the identified subsystems. The model is based on the honeycomb principle: the nucleus (an emergency medical assistance subsystem) and six components, encircling the nucleus and interrelated by direct or indirect (through another component of the model) internal links: a control subjects subsystem, a resource subsystem, a patient flow management subsystem, an inter-hospital transportation subsystem, an information subsystem, and a public's education and information subsystem. 


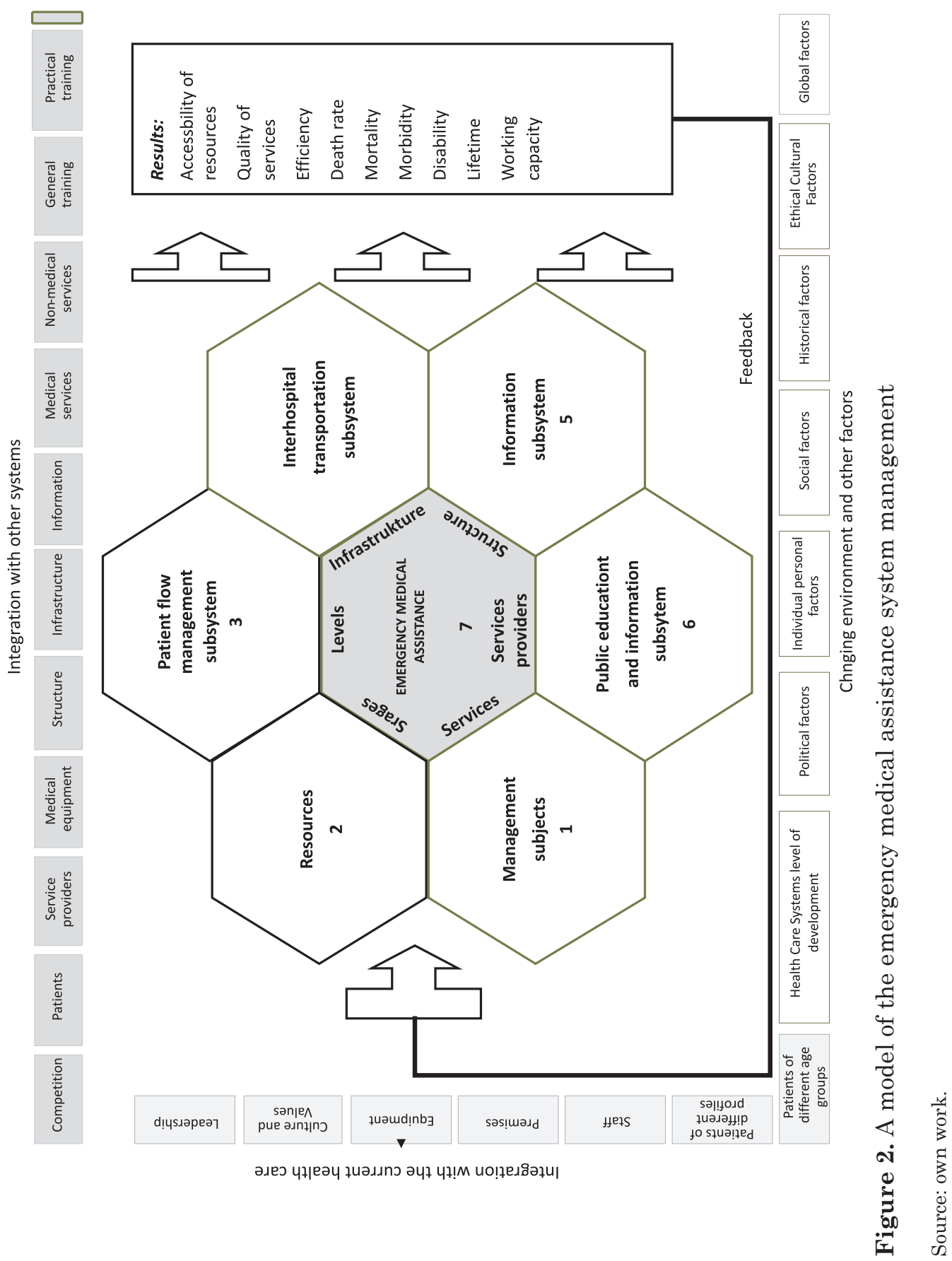


The operation of the model is based on the common management (information, organisation, systems analysis, etc.) and service provision (diagnostics, treatment, nursing, transportation, etc.), processes, management methods (organisational, legal, combined, etc.), and management functions (information, forecasting, planning, organisation, motivation, coordination, management, control, and adjustment). The model is based on a mixed prehospital EMA services' provision principle. The model is based on the EMA services' provision by the health care medical staff and military medical personnel. The model ensures the management of external and internal EMA patient flows. The evaluation of a patient's condition is based on a five-level triage system and condition evaluation protocols and standards. Under the model, services are provided in 4 stages: prehospital, hospital, inter-hospital, and post-hospital. Primary, secondary, and tertiary transportation is ensured between different medical institutions providing hospitalisation services. The accessibility and quality of EMA services is ensured by a set of the quantitative and qualitative indicators and their monitoring. Decision making in the model is based on the information processed by the information system. The model ensures the public's information and education on EMA issues. The model ensures staff training and professional development. In the model, the goals of the system are arranged on the hierarchical management principle, and the result achievement is controlled. Given the requirements of the changing environment and the goals of the EMA system, the improvement of management takes place.

The main factors that influence the changes in patient flows are the factors that predetermine the demand and supply of health care services. The factors that predetermine demand include demographic changes (declining birth rates and aging), the changes in the epidemiological situation (an increasing number of patients with chronic non-communicable diseases, after traumas and other external injuries), etc. The factors predetermining supply include the fragmentation and segmentation of services, the focus on hospital activities and insufficiently functioning primary health care centres, a shortage of resources, and simultaneously advances in medical technologies. The demand and supply factors affect the fields and changes in the health care system caused by the health reform carried out by management subjects. Due to the changes in the health system, in some medical institutions patient flows decrease, while in others they increase. 
Because of disproportionately decreasing EMA patient flows in some institutions and increasing flows in other ones, systemic decisions are necessary to implement the measures for the EMA system management improvement, approved during the survey. The decisions to choose the measures indicated in the model are justified by theoretical analysis and empirical research.

The implementation of the decisions through the introduction of the approved measures is based on the optimisation of triage and human resources, the introduction and development of information technologies, the identification of the qualitative criteria for EMA services, and the optimisation of all the hospital resources. The principal triage optimisation is planned in the following fields: introduction of five EMA levels; introduction of triage scales, adapted for the evaluation carried out by nurses; introduction of protocols, algorithms, and standards for patient inter-hospital transfer and for the patient condition evaluation in general and in individual cases, recording the EMA level on the ambulance record sheet; introduction of condition evaluation scales for hospital patients and outpatients, adults and children.

On average, in 2015, the correlation of doctors and nurses in Lithuania was 1: 1.85 , while the desired correlation for 2020 is 2 nurses per 1 doctor (Ustinavičienė \& Želvienè, 2016). A shortage of nurses is proposed to be compensated by training specialised nurses with the skills to evaluate a patient's condition. In general, the issue of human resources optimisation is proposed to be addressed in the following fields: the extension of the GP job description; optimisation of the GP number and their retraining; training of EMA nurses; the use of military medical personnel for the EMA provision in the EDs of the national and university-level hospitals; assigning of additional consultants for work in EDs; introduction of the job of emergency physician (specialists of the profile have already started to be trained).

The identification of the EMA services qualitative criteria solves the problem of the assurance of EMA services quality provision and their accessibility. The assurance of the EMA services accessibility and their quality provision is to be achieved in the following ways: the establishment of the duration of EMA service provision in all the stages of EMA services provision; the evaluation and comparison of triage scales at the ED and AS levels in hospitals; the evaluation and comparison of the level of use of condition evaluation protocols in 
hospitals in case of patients' transfer from one hospital to another; to have the number of patients leaving EDs without examination (patients that failed to get doctors' examination) amounting to no more than $3 \%$ from the total number of the patients visiting EDs.

The optimisation of all hospital resources removes or reduces the internal factors that may increase the ED occupancy. The proposed measures include the introduction of a fee for non-emergency medical assistance provision in the ED, increased funding, optimisation of the number of staff, etc.

The implementation and development of information technologies solves the problems of integration and cooperation between the institutions providing health care, education, and social services, as well as with the general public and individuals, and promote people's responsibility for their own health. The implementation and development of information technologies is proposed to be developed in the following fields: the introduction of the EMA service provision information service; patients' education and training; dissemination of educational materials for self-help and self-care; the development and implementation of e-health mobile applications.

The introduction and development of information technologies are interrelated by internal links with the information and public's education subsystems. The goals of the latter subsystem include the teaching of patients and their families to provide first aid to themselves and others; identification of the state of health; accessibility of health care institutions and primary treatment; and general public information about the prevention of traumas and acute health disorders. The principal goal of the information and public education subsystems is to turn public education and teaching into a continuous process, regularly supplemented with the latest knowledge and contemporary technologies.

\section{CONCLUSIONS}

The outcomes of the conducted research identified potential management improvement opportunities in individual parts of the emergency medical assistance system. The following measures for the improvement of the emergency medical assistance system management were proposed that sought to improve the EMA system efficiency and to ensure the 
accessibility and quality of its services: uniform application of systematised concepts, triage optimisation, identification of the quantitative and qualitative indicators of emergency medical assistance, greater empowerment for the nurses, the use of the military medical personnel in the medical institutions providing EMA services, the regulation of external and internal patient flows, the development of a long-term emergency medical assistance operational program and activity coordination, the regulation of payment for EMA and non-EMA services, and appropriate public information and education.

The development of the concepts of the emergency medical assistance system management as well as emergency medical assistance are related to human health and a life-threatening and rapidly changing environment. That partly accounts for the interdisciplinary and different approach of scientists from various areas to the research object. The author of the dissertation defines the concepts in the following way: the EMA system implies the staff of emergency medical assistance, the infrastructure, the funds, and other elements of the system and the relations between them that ensure effective, accessible, and high quality local, regional, or national emergency medical assistance services; the EMA system management implies the assurance of the system functioning through the related management bodies, processes, and measures in pursuit of the goals of accessibility and high quality set for the EMA system.

\section{REFERENCES}

Anthony, D.R. (2011). Promoting emergency medical care systems in the developing world: weighing the costs. Glob Public Health, 6(8), 906-913.

Dèl Lietuvos sveikatos sistemos 2011-2020 metu pletros metmenu patvirtinimo (2011). Lietuvos Respublikos Seimo 2011 m. birželio 7 d. nutarimas Nr. XI-1430. Valstybès žinios, Nr. 73-3498.

Donaldson, C. (1996). Purshasing to Meet Need. Reforming Health Care Systems. Cheltenham: British Association for the Advancement of Science.

Global Forum on Trauma Care (2009). Meeting report. Rio de Janeiro, 28-29 October. http://www.who.int/emergencycare/trauma/global_forum_meeting_report. pdf?ua=1 (access: 2017.09.17).

Hodkinson, P.W. \& Walis, L.A. (2010). Emergency medicine in the developing world: a Delhi study. Academic Emergency Medicine, 17(7), 765-774. 
Kaluzny, A.D. \& Shortell, S.M. (2006). Organization Theory and Health Services Management. Health Care Management: Organization Design and Behaviour. NY: Thomson Delmar Learning, p. 8.

Principles of Emergency Management (2007). EM Public safety, public trust. https:// www.ndsu.edu/fileadmin/emgt/PrinciplesofEmergencyManagement.pdf (access: 2017.09.17).

Tintinalli, J.E., Cameron, P. \& Holliman, C.J. (2010). EMS: A Practical Global Guidebook. PMPH-USA.

Ustinavičienè, R. \& Želvienè, A. (2016). Lietuvos sveikatos 2014-2025 m. strategijos vykdymas: kaip sekasi siekti užsibrëžtu tikslu? Visuomenès sveikatos netolygumai, 2(15). Vilnius: Higienos institutas.

VŽ, No. 73-3498, 2011. 


\title{
POPRAWA ZARZĄDZANIA LITEWSKIM SYSTEMEM POMOCY MEDYCZNEJ
}

\begin{abstract}
Abstrakt
Tło badań. W artykule omówiono kwestię poprawy działania systemu pomocy medycznej w nagłych wypadkach na Litwie. Reforma opieki zdrowotnej na Litwie trwa już od trzech dekad, ale pomimo świadomości, że zarządzanie opieką zdrowotną musi być skuteczne i metodycznie poprawne, nie można jej nazwać spójną, kompleksową i dobrze skoordynowaną. Autorzy zajmuja się metodami adaptacji systemu pomocy medycznej na Litwie do zmieniających się czynników środowiskowych, postępu nauki i technologii informacyjnych oraz do prawnych wymagań Światowej Organizacji Zdrowia i UE.
\end{abstract}

Cel badań. Celem tego badania było zdefiniowanie kluczowych pojęć pomocy medycznej w nagłych wypadkach, przeanalizowanie modeli systemów pomocy w nagłych wypadkach w innych krajach i wykorzystanie uzyskanych wyników do stworzenia teorii zarządzania pomocą w nagłych wypadkach, określenia braków w litewskim ratownictwie medycznym systemie pomocy, a także zaproponowanie narzędzia do jego ulepszenia i zdefiniowania podsystemu zarządzania pomocą w ratownictwie medycznym.

Metodologia. Metody badawcze obejmuja ilościowe badania opisowe przy wykorzystaniu usystematyzowanej ankiety; analizę danych statystycznych (chi-kwadrat, średnia), modelowanie i reprezentację graficzna. Wewnętrzna spójność skali kwestionariusza została oceniona za pomocą współczynnika alfa Cronbacha.

Kluczowe wnioski. Obszary problemowe pomocy medycznej w nagłych wypadkach pogrupowano w zależności od ich wpływu na sytuację społeczną lub gospodarczą kraju. Było to podstawą usprawnienia zarządzania i integracji pomocy medycznej w nagłych wypadkach. Opracowano model zarządzania systemem pomocy medycznej w nagłych wypadkach na Litwie, oparty na zasadzie systemowej, w której integralne części są powiązane wewnętrznymi relacjami między podmiotami zarządzania opieką zdrowotna; zasoby; i wyniki. Opracowano pięć podsystemów: nadzór nad awaryjną pomocą medyczna, transport między szpitalami pacjenta, informacje i zarządzanie przepływem pacjentów, a także edukację publiczną i informacje.

Słowa kluczowe: pomoc medyczna w nagłych wypadkach (EMA), doskonalenie, zarządzanie, system. 